\title{
Infection of the isopod Tachaea spongillicola on freshwater prawns Macrobrachium spp. in southern India
}

\author{
Pitchaimuthu Mariappan ${ }^{1, *}$, Chellam Balasundaram ${ }^{1}$, Jean-Paul Trilles ${ }^{2}$ \\ ${ }^{1}$ Department of Animal Science, Bharathidasan University, Tiruchirapalli 620 024, India \\ ${ }^{2}$ Laboratoire d'Ecophysiologie des Invertébrés, Université Montpellier II, Sciences et Techniques du Languedoc, CP 092, \\ Place Eugéne Bataillon, 34095 Montpellier Cedex 5, France
}

\begin{abstract}
This paper reports the infection of freshwater prawns belonging to the genus Macrobrachium by the isopod parasite Tachaea spongillicola in a freshwater river system of southeastern India.
\end{abstract}

KEY WORDS: Isopod - Tachaea spongillicola $\cdot$ Freshwater prawn $\cdot$ Macrobrachium

Resale or republication not permitted without written consent of the publisher

Isopods are dorsoventrally flattened peracarid crustaceans that are free-living scavengers, commensal partners or parasites. Of approximately 10000 described species in 10 suborders, ca. 5000 are terrestrial, 4500 are marine and 500 are freshwater with a wide distribution over highly varied habitats (Kensley \& Brusca 2001). Ectoparasitic isopods can pose serious problems by infecting fishes and crustaceans in the wild and in aquaculture (Koesharyani et al. 1999, Papapanagiotou et al. 1999, Kent 2000, Papapanagiotou \& Trilles 2001, Thatcher \& Blumenfeldt 2001). Indian ocean isopods, including parasites, have recently been reviewed by Kensley (2001).

During field studies on the diversity, biology and behaviour of freshwater prawns, conducted between June 1997 and January 2000, we found isopod infections on Macrobrachium nobilii, M. lamarrei and $M$. malcolmsonii from 3 sites along the course of the Cauvery River near Tiruchirapalli, South India (Fig. 1). Jedarpalayam, the farthest collection site, is at a distance of ca. $400 \mathrm{~km}$ from the Bay of Bengal.

The isopod was identified as Tachaea spongillicola Stebbing, 1907 based on the description provided by Stebbing in 1907. T. spongillicola was first collected from a freshwater tank from the freshwater sponge Spongilla carteri. Hence, the name of the species is derived from that of the sponge. The distribution of the 6 species of the genus Tachaea is more restricted than that of other species in related genera of the family
Coralallanidae (Delaney 1989). With the exception of T. crassipes, other species are recorded from freshwater habitats as ectoparasites of fishes and prawns. However, T. spongillicola has been collected only as a commensal of the freshwater sponges $S$. carteri and $S$. lacustris (Stebbing 1907). Thus, this is the first report of $T$. spongillicola being collected as an ectoparasite of freshwater prawns.

Although earlier studies describe bopyrid isopods as common parasites of Macrobrachium spp. (Ibrahim 1962, Markham 1985, Oliveira 2000), the occurrence of the cymothoid isopod Telotha henselli (von Martens) on $M$. brasiliense (Heller) is considered as exceptional (Lemos de Castro 1985). Infection of corallanid isopods of the genus Tachaea on freshwater prawns that

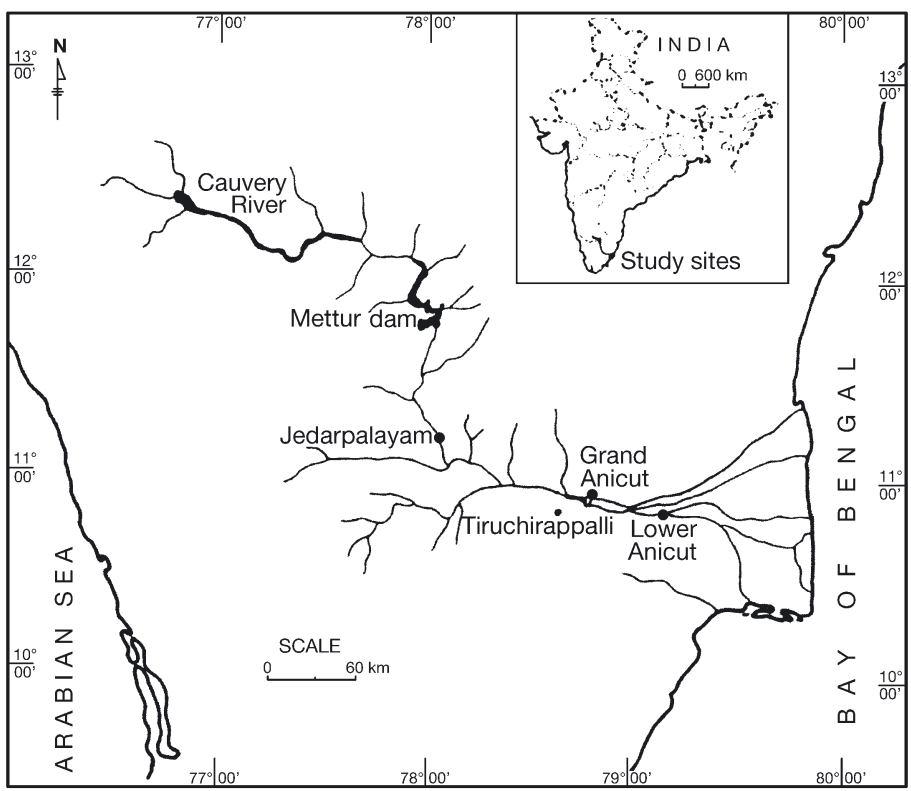

Fig. 1. Map showing study sites $(\bullet)$ on the Cauvery River 




Fig. 2. Tachaea spongillicola. Dorsal and ventral view

belong to the genera Palaemonetes, Leander, Paratya, Macrobrachium and Caridina (Riek 1953, 1967, Delaney 1989) has been reported. Though the percentage of occurrence of $T$. spongillicola on the specimens collected for this study was low (ranging from 1.06 in M. malcolmsonii to 1.61 in M. nobilii, Table 1), it is worthy of mention that the infection was found on species like M. nobilii (Balasundaram \& Pandian 1982) and M. malcolmsonii (Kelwalramani 1973) that migrate between fresh and marine water. Whether $T$. spongilli-

Table 1. Tachaea spongillicola infection on Macrobrachium spp. Prevalence $(\%$, numbers in parentheses) on 3 species of freshwater prawns at 3 collection sites. NR: not recorded

\begin{tabular}{|lccc|}
\hline Host species & \multicolumn{3}{c|}{ Prevalence of Tachaea spongillicola } \\
& Jedarpalayam & Grand Anicut & Lower Anicut \\
\hline M. nobilii & $1.61(5 / 310)$ & $1.47(7 / 475)$ & $1.54(3 / 194)$ \\
M. lamarrei & $1.07(2 / 186)$ & $1.52(3 / 197)$ & NR \\
M. malcolmsonii & NR & NR & $1.06(8 / 751)$ \\
\hline
\end{tabular}

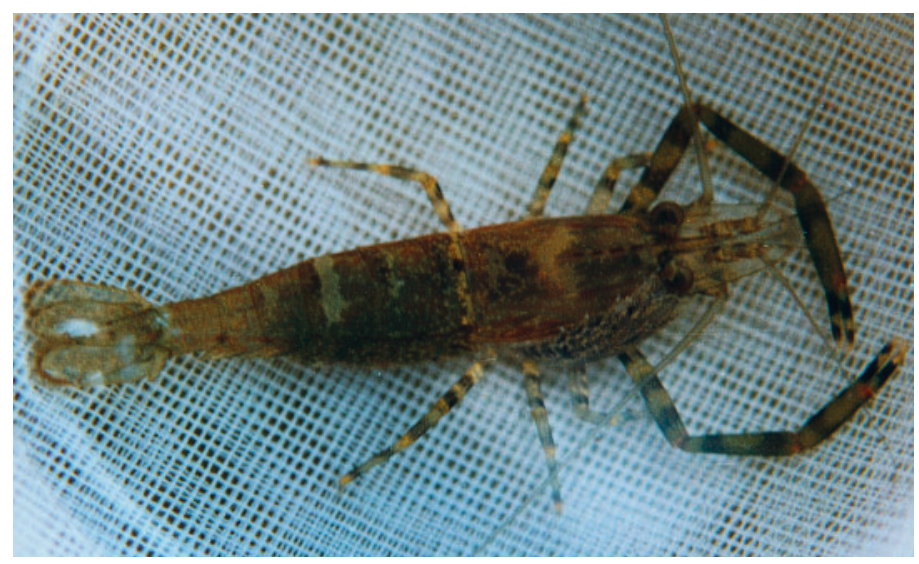

Fig. 3. Macrobrachium nobilii. Berried prawn with parasite clinging to the right carapace near the chela

Editorial responsibility: Timothy Flegel,

Bangkok, Thailand cola remains with them throughout their migrations (i.e. whether it is also present in marine water) merits further investigation.

Acknowledgements. P.M. gratefully acknowledges the CSIRGovernment of India for financial assistance in the form of a Senior Research Fellowship award (1998-2002). The authors are also indebted to those who provided relevant literature.

\section{LITERATURE CITED}

Balasundaram C, Pandian TJ (1982) Yolk energy utilization in Macrobrachium nobilii (Henderson and Matthai). J Exp Mar Biol Ecol 61:125-131

Delaney PM (1989) Phylogeny and biogeography of the marine isopod family Corallanidae (Crustacea, Isopoda, Flabellifera). Cont Sci Nat Hist Mus LA 409:1-75

Ibrahim KH (1962) Observations on the fishery and biology of the freshwater prawn Macrobrachium malcolmsonii Milne Edwards of river Godavari. Indian J Fish 9:433-467

Kelwalramani HG (1973) Salinity requirements in the larval history of freshwater prawn Macrobrachium malcolmsonii H. Milne Edwards. Spec Publ Mar Biol Assoc India 362-365

Kensley B (2001) Biogeography of the marine Isopoda of the Indian Ocean, with a check-list of species and records. Crustac Issues 13:205-264

Kensley B, Brusca RC (2001) Isopod systematis and evolution. Crustac Iss 13:313-320

Kent ML (2000) Marine netpen farming leads to infections with some unusual parasites. Int J Parasitol 30(3):321-326

Koesharyani I, Zafran, Yuasa K, Hatai K (1999) Two species of capsalid monogeneans infecting cultured humpback grouper Cromileptes altivelis in Indonesia. Fish Pathol 34: 165-166

Lemos de Castro A (1985) Ectoparasitism of Telotha henselii (von Martens) (Isopoda, Cymothoidae) on Macrobrachium brasiliense (Heller) (Decapoda, Palaemonida). Crustaceana 49:200-201

Markham JC (1985) A review of the bopyrid isopods infesting caridean shrimps in the Northwestern Atlantic Ocean, with special reference to those collected during the Hourglass cruises in the Gulf of Mexico. Mem Hourglass Cruises 7(3):1-156

Oliveira E (2000) The population structure of Probopyrus floridensis (Isopoda, Bopyridae). A parasite of Macrobrachium potiuna (Decapoda, Palaemonidae) from the Pereque river Paranagua Basin, South Brazil. Crustaceana 73:1095-1108

Papapanagiotou EP, Trilles JP (2001) Cymothoid parasite Ceratothoa parallela inflicts great losses on cultured gilthead sea bream Sparus aurata in Greece. Mar Ecol Prog Ser 45:237-239

Papapanagiotou EP, Trilles JP, Photis G (1999) First record of Emetha audouini, a cymothoid isopod parasite, from cultured sea bass Dicentrarchus labrox in Greece. Dis Aquat Org 38(3):235-237

Riek EF (1953) A Corallanid isopod parasite on freshwater prawns in Queensland. Proc Linn Soc NSW 77(5-6):259-261

Riek EF (1967) A new Corallanid isopod parasite on Australian freshwater prawns. Proc Linn Soc NSW 91:176-178

Stebbing TRR (1907) A freshwater isopod from Calcutta. Zool J Linn Soc (Lond) 30:39-41

Thatcher VE, Blumenfeldt CL (2001) Anilocra montti sp. n. (Isopoda, Cymothoidae) a parasite of caged salmon and trout in Chile. Rev Bras Zool 18(Suppl. 1):269-275

Submitted: March 18, 2002; Accepted: April 18, 2003

Proofs received from author(s): July 7, 2003 